\title{
Urban Women Week: Promoting Women on the Senegalese Rap Scene
}

\author{
Cécile Navarro \\ University of Lausanne, Institut des Sciences Sociales des \\ Religions \\ cecile.navarro@unil.ch
}

\begin{abstract}
The growing interest in gender equality at festivals contrasts with the relative lack of scholarly attention given to festivals as sites of gender politics. Organized by a Senegalese association which promotes urban cultures, the example of Urban Women Week - a Senegalese festival which aims to promote women in hip hop, including rap music - leads me to revisit a gendered perspective on festivals while tackling the neglected issue of women's presence in a rap music scene dominated by the "patriarchal impulses of the Senegalese hip hop establishment" (Neff 2015: 460). How are we to understand the adoption of a focus on women by the organizers of the festival in Senegal? Is rap music a specific place where women are empowered in the Senegalese context? Based on fieldwork carried out on the rap music scene in Senegal, I situate the establishment and evolution of the festival as a way for the association to respond to local claims for the inclusion of women in rap music while benefiting from a global agenda of gender mainstreaming, thereby exploring the glocal intricacies of gender politics in music.
\end{abstract}

KEYWORDS: festival, gender, glocalisation, rap, Senegal

\section{Introduction: Gender politics in festivals}

During 2017 and 2018, we have seen advances in awareness of the inequalities between men and women around the world and in all areas of society, but most particularly in the entertainment industry (first film and later music), where the scandal of sexual harassment initially exploded.

The small number of female acts appearing at festivals is an issue that has attracted more attention this year (2018) than previously. According to Mitchum and Garcia-Olano (2017) for Pitchfork, only 14\% of the nearly 1,000 performers booked to appear at twenty-three leading US and Canadian festivals in 2017 were female, with another $12 \%$ of acts either involving both men and women or not identifying in binary gender terms. Given the importance of live performances as a 
source of income for artists affected by the current crisis in the recorded music industry, poor programming of women at festivals can be seen as just the tip of the iceberg concerning the general lack of opportunities for women in the music industry but also as one problem that can be addressed fairly easily. In 2017, the PRS Foundation music charity launched Keychange, an international initiative aimed at encouraging festivals to strike an equal gender balance across festival lineups.

This growing interest in gender equality at festivals contrasts with the relative lack of scholarly attention given to festivals as sites of gender politics. According to Getz (2010), three major discourses can be identified in what he calls "festival studies": festival tourism; event management; and studies on the roles, meanings and impacts of festivals in society and culture (a discourse which generally emerges from sociological and anthropological perspectives). From this third point of view, festivals have been primarily seen as spaces for the articulation, performance and rediscovery of identity (Aitchison and Pritchard 2007). This view of the festival encompasses discussions about gender at festivals, particularly in the United States, through the expression of feminist, lesbian and gay political identities in specific settings, as shown in the ethnographic accounts of women-only festivals like the National Women's Music Festival (Eder, Staggenborg and Sudderth 1995) or the Michigan Womyn's Music Festival (Higgins 2008), and of lesbian and gay film festivals (Gamson 1996). In these accounts, festivals - whether of music or of film - are seen as sites of community building within a feminist framework.

Other studies concerning women at music festivals outside the United States have focused on festivals as sites of performance of national gender identities in the light of the role of music in the performance of the nation (Askew 2002). For example, DeBano (2005) has explored how state-sponsored women-only festivals question specific concepts of womanhood, Islam and the state in post-revolutionary Iran. Festivals there are used both by the state to promote a certain ideal of womanhood and by their participants to discuss and even subvert gender categories.

Nevertheless, few studies on music festivals have addressed the strategies of actors in the music industry themselves to encourage or implement gender agendas, as has been done in the case of contemporary women's film festivals (Maule 2014). I use the case of Urban Women Week (UWW) to both understand the development of gender politics in countries like Senegal and issues of women's presence on a Senegalese rap music scene, identified by Ali Colleen Neff as one which is dominated by the "patriarchal impulses of the Senegalese hip hop establishment" (Neff 2015: 460).

How are we to understand the adoption of a gendered perspective by Africulturban, the organizers of the festival in Senegal? Is rap music a specific place where women are empowered in the Senegalese context? This article begins with some brief comments on feminist and women's struggles in Senegal before underlining the specificity of rap music in that country and the place of women on the rap music scene. These introductory remarks lead on to a discussion of UWW as an example of gender politics in the music industry of a non-Western country. Based on fieldwork carried out on the rap music scene in Senegal, I situate the establishment and evolution of the festival as a way for the association to respond to local claims for the inclusion of women in rap music while benefiting from a global agenda of gender mainstreaming, thereby exploring the glocal intricacies of gender politics in music. 


\title{
Gender, society and religion in Senegal
}

\begin{abstract}
It's normal that in conservative societies people don't surrender power easily. Nobody wants to lose their privileges. Nobody wants to go away and clean the bogs. It's a scam. Nobody wants to go away and cook the rice. That's also a scam. Overall, it's about who stands to lose power. It's all about domination. (French female rapper Casey ${ }^{1}$ during the conference organized on Urban Women Day in 2015, answering to a question posed by a member of the audience to several female rappers on their experiences in a male-dominated environment. Translation from original quote in French by the author)
\end{abstract}

In 2015, I attended Festa $2 \mathrm{H}$, one of the biggest international hip hop festivals in Africa. The event is also organized by Africulturban, the same association that runs UWW, and whose objective is to promote urban cultures in the West African country of Senegal. Festa $2 \mathrm{H}^{\prime}$ s programme included one day ("Urban Women Day") dedicated to the role of women in hip hop. At the time, I had come to the end of a year's worth of intermittent fieldwork amongst (mostly male) individuals involved in the Senegalese rap music scene. During these periods, I lived in Dakar, the capital of Senegal and the country's main centre for rap music. The fieldwork was part of a doctoral research project on the Senegalese rap music scene, defined as a collective of individuals involved in the making, performance and reception of a type of music they described as a form of rap embedded in a local context (i.e. Dakar and its suburbs). The music scene was framed within the research as both a spatial and a social space, and my research also addressed the way it was both constituted and transformed by the circulation of objects, images, technologies and people (Bennett and Peterson 2004). For example, the above statement made by French female rapper Casey at the hip hop festival allowed for a discussion on inequalities between men and women anchored into issues of power to take place in a country where such views rarely get to be expressed in that particular way.

In an interview with Thérèse Locoh and Isabelle Puech, Senegalese women's rights activist and academic Fatou Sow shares the challenges of being a feminist in Senegal:

The issue of inequalities between men and women was long to come, African women were not ready to hold it in public, against colonial and post-colonial exploitation. The discourse 'against men' was perceived as a discourse against Africa, against African cultural values. (Fatou Sow in Locoh and Puech 2008: 12., translation from original quote in French by the author)

She also explains how African feminism has progressively emerged through two claims: the right for African women to speak on their own conditions; and the awareness about the differences of realities and priorities between African and Western women.

According to Dial (2008), Senegalese society is based on the idea of a hegemonic masculinity that is ultimately rooted in religion $(95 \%$ of Senegalese inhabitants describe themselves as Muslim), and tradition (Wolof being the dominant ethnicity, both in terms of numbers and of its importance in shaping the national character of Senegal. It does so mainly through the language, Wolof, spoken and/or understood by the majority of the population). Historically, these have together provided the framework for the formation of the Senegalese nation state during and since the colonial era. 
Since the eleventh century, Islam has gradually become the main religious belief in Senegal until the emergence of Sufi brotherhoods at the beginning of the twentieth century at the benefit of a particular political context (Triaud 1995). Most Senegalese today belong to the Tidjane, Murid, Xaadir or Layene brotherhoods. Brotherhoods can be defined as religious organizations made of talibes ("disciples") emulating the "path" followed by the Cheik (religious leader) on their path to Allah. Since independence in 1960, the Constitution of Senegal has guaranteed the secularism of the state. Nevertheless, the country's first president, Léopold Sédar Senghor, worked to gather support from leaders of the religious brotherhoods in order to strengthen the legitimacy of the new state (a strategy already practised by the former French colonial power).

Contemporary relationships between religious and political leaders are extremely complex (as discussed by Salzbrunn 2012 and Gifford 2016) but one consequence of this is the difficulty of establishing political agendas on matters involving religious dogma and interests. Despite the importance of feminist movements in Senegal, one such issue is gender equality. Sow (2003) points out how a recent rise in religious fundamentalism in Senegal conflicted with the promotion of women's rights. For instance, although Macky Sall's government managed in 2012 to implement the gender parity law in favour of equal access of women and men to elected office (voted by former president Abdoulaye Wade in 2010), the authorities of Touba, holy city of the Murid brotherhood, have flatly refused to apply it and have not been forced to do so by the government.

Widespread masculine migration (Mondain et al. 2012) and the economic and demographic crises that Senegal has endured since the eighties (Biaya 2001; Vignikin 2007) have also transformed expected gender roles. In Senegal, therefore, as in other African and Muslim countries, the place of women is at the heart of most current debates on globalization and modernity. Although there are numerous women's associations and initiatives - most notably the Senegalese Council of Women (Conseil Sénégalais des Femmes, COSEF) - the fight for women's rights is not taking place primarily in the context of a struggle against a patriarchal system but in that of perceived relationships of interdependence, complementarity and partnership between men and women.

UWW is not the only festival that has tried to promote women's rights in Senegal. However, as a hip hop festival, it does explicitly address the role of women outside the domestic sphere and outside gender norms by acknowledging the presence of women in a male-dominated field.

\section{Women in the Senegalese rap scene}

Numerous studies have attested to the predominance and hegemony of masculinity in rap music both in the United States (Cheney 2005; White 2011) and elsewhere, including in African countries (in Gabon, see Aterianus-Owanga 2013; and in East Africa, see Ntarangwi 2009). Misogynistic attitudes and portrayals of violence against women are prevalent in American rap lyrics and videos (Pough 2007). This is particularly the case in gangsta rap, a subgenre based on the representation of the hyper-masculine rapper, which has been explored by researchers as a strategy of reversal of stereotypes on black sexualized bodies (De Genova 1995) or as the result of the commodification of black popular music in order to please a mainly white middle-class audience (hooks 1992). Consequently, a taste for rap music has never been without contradictions for feminists (as noted by Jeffries 2012), while some activists have tried to push an agenda of hip hop feminism in order to discuss 
issues of gender, class, race and sexuality (see Pough 2007). However, women have always taken part in the production of hip hop music. Roxanne Shante, Queen Latifah, Mc Lyte were among the pioneering MCs, and the first of many talented women in rap music.

In Senegal, too, hip hop is mainly considered as a male scene. Indeed, it is regarded as a culture of young men, destined to pass with time and with the responsibilities that come with age. However, according to Diop (2012) and her research into Senegalese feminine transgressive figures she calls les scandaleuses ("the scandalous"), masculine transgression is met with less concern in Senegal than female transgression. That is why, as Senegalese slam and graffiti artist Zeinixx told blogger Mona Munck-Lindblom for the Rapolitics site:

Those who are not involved in the hip hop movement think that I and the other women in the movement are bitches. Especially the older generations tend to think that hip hop culture is steeped in sin, and being female only makes it worse in their eyes. (Munck-Lindblom 2014)

When I asked Senegalese female rappers about their debuts in rap music, they all said that their families thought rap music was for men. Deése Major told me about the reactions of her aunt (who had raised her) whenever she said she was going to rap:

(M)a tante me disait:" Toi tu es folle". Tu vois ? Comment tu peux choisir une musique comme le rap, tu es une femme". ("My aunt used to tell me 'You're crazy'. You see? 'How can you choose a music like rap? You're a woman.'").

When women do choose to perform hip hop, dominant gender norms and expectations in Senegalese society once again influence their decision to pursue an artistic career. Moona, another female rapper I interviewed felt that many women stopped making music for fear of not being able to find a good husband.

Being a woman also affects the extent to which female artists are accepted on the music scene. While Senegalese rap has been mostly free of sexualized portrayals of women in lyrics and videos, its representation of women oscillates between the celebration of an idealized womanhood and the condemnation of forms of behaviour seen as reprehensible. Love songs like Elzo Jamdong's 2016 "Yow Lë" (Oven Entertainment) illustrate the conservative views of such relationships that are prevalent among rappers. The artist raps: "Yaaye doon ki jour samay doom, Someu deggelul damay dof". " You'll be the mother of my children, I'll be mad if you don't obey me").

Sexualized portrayals of women are thus perceived as damaging to the dignity of African women, while women are at the same time considered as particularly subject to moral depravity (Diouf 2002: 284). It is therefore the responsibility of the male rapper, as it is the responsibility of all men in society, to protect women from harm, including the harm they are liable to inflict on themselves.

Thus, while women within the scene are sometimes supported by their male peers, they are usually expected to respect certain norms. According to the accounts of the three female rappers I interviewed during my fieldwork, they faced comments on their appearance (deemed either too masculine or too sexy) and their delivery (at times considered too aggressive). This is reflected in the media coverage of female Senegalese rappers more widely. For example, the outfits of Déesse Major have created quite a stir, with the Comité pour la défense des valeurs morales au Sénégal ("Committee for the defence of moral values in Senegal") twice accusing 
her of public indecency. She was arrested for that offence on 17 June 2016 and only released three days later (Mine, 2016). Her arrest sparked debate in the rap scene about whether she had gone too far or whether she had the right to dress as she pleased. Few rappers (male or female) approved of her outfits, but most thought that artists had the right to express themselves. This represents a complex situation for artists to negotiate.

It became clear during my fieldwork that women also face specific obstacles to success in the industry. Firstly, women were considered less talented than men. Secondly, based on my observations in the field, female rappers were mostly absent or strongly in the minority on radio and television programmes dedicated to rap, as well as in live concerts. Of the 27 concerts and events I attended in Senegal and abroad about Senegalese rap, only 9 had at least one female rapper perform (with the exception of events dedicated specifically to women in Senegalese rap). From those 9, 7 had only one female rapper, one was the concert of female rapper Toussa and one was organized by a programme of the American Department of State).

Since most people involved in rap music (promoters and producers) are men, female rappers are offered fewer opportunities on the grounds that they seem to be less in touch with a perceived male-dominated audience. Finally, men in roles of producers and promoters are reluctant to invest in female careers that they feel will end when the artist marries and has children. This is despite the fact that some men also stop making music when they marry in the search for a less precarious professional activity. Thus, as stated by Buscatto (2008) for women jazz musicians, challenges for women in Senegalese rap can also be summarised as relating to attempting, entering and staying within the scene.

Despite these specific obstacles, some female artists have succeeded in establishing a career. In 2017, female rapper Moona became the first Senegalese artist to sign a record deal with Sony Music Entertainment. Toussa is another example. After participating in a few local contests, usually as the only female artist, Toussa was selected by the American Word, Beats and Life programme and toured the United States with other musicians from around the world. With the money she earned, she built a studio in her home neighbourhood of Guédiawaye, a suburb of the Senegalese capital, and called it "Studio Fam", a reference both to 'family' and to the French word femme (woman). Toussa has recently signed a contract with Senegalese/American label Y.B.E. The song "Caractère" from her new mixtape, featuring American rapper SK, attracted 400,000 views on YouTube: a record in Senegal.

Over the last five years, many other female performers have emerged in rap music and related hip hop disciplines: O.M.G, Mamy Victory, Mina La Voilée, Eve Crazy, the all-female rap group G.O.T.A.L, graffiti artist and slam performer Zeinixx, DJ Zeyna, DJ Nina and plenty more. The Galsen Hip Hop Awards were actually expanded in 2016 to include a new category of "best female rapper".

Thus, rap is emerging as a major arena for the empowerment of women in Senegal: an arena in which they can potentially prove their worth to male counterparts and emancipate themselves from perceived gendered roles. If their involvement in the culture is at first deemed unacceptable by families, friends and neighbours, achieving success in hip hop helps women to gain a new legitimacy, proving that women can succeed in a male-dominated arena. This legitimacy is also reinforced at a time in which the involvement of rappers in Senegalese political life is bringing rap music itself more into mainstream society (Niang 2013). Through recent initiatives like the $Y^{\prime}$ en a marre ("Fed Up") movement, whose members have earned international recognition for their militancy for better governance and civic 
behaviour, rap in Senegal is now being presented as an instrument of nationwide social change.

According to Mamadou Diouf (2002), rap music has served as the expression of the will of younger people to break with the values of previous generations. Rap therefore contains the potential to act as an instrument of change. Nevertheless, as the description of the condition of women in Senegalese rap has shown, rap can also still be a place in which conservative values prevail. In the remainder of this article, I will examine the way UWW has positioned itself on the issue of women's presence in Senegalese rap before discussing the gender politics of UWW itself.

\section{Urban Women Week: Promoting women in the Senegalese hip hop scene}

Urban Women Week (UWW) is a festival launched to coincide with International Women's Day (8 March) and to promote the presence of women in Senegalese 'urban cultures', a term used by Africulturban, a hip hop association headed by famous Senegalese rapper Matador and located in the suburbs of Dakar. The association uses the term to refer to hip hop culture and other urban practices which, in Senegal, involve rap, graffiti, hip hop dancing and roller skating. During an interview with the association's general secretary, Amadou Fall Ba explained the association prefers the term because - in addition to allowing for the inclusion of different disciplines of hip hop - its use makes it easier, in a country where terms like rap and hip hop have political connotations, to obtain support from state officials and international partners alike.

In fact, most of the association's funding comes from various embassies and international organisations. Amadou Fall Ba has stated during a conference about entrepreneurship in Senegalese rap that $97 \%$ of its resources are provided by nonSenegalese partners. Indeed, the government has long been both unable and unwilling to sustain the development of the Senegalese hip hop scene or, indeed, the cultural scene as a whole. A new state fund to support 'urban cultures' has been set up since 2016, the effects of which remain to be seen in changing the crucial role of foreign agencies in financing hip hop in Senegal.

In 2012, the US State Department supported the opening of a hip hop training school launched by the association. Among its students was a young woman, known by the name of Ina, who was studying audio-visual production. She got in touch with the school in 2010 through a friend of hers, a DJ who is also involved with the association and with whom she used to play basketball. She spent some time in the school's studio learning the production process before taking the lessons of the training school and getting involved in the management of the school's documentation centre. The centre makes books, CDs and DVDs on hip hop culture available and keeps track of the different music events in order to participate in recording and archiving developments in Senegalese hip hop. Ina started taking pictures at concerts and events as a way of documenting the Senegalese rap and hip hop scene. She is now the only woman among the twelve permanent members of the association team. Her involvement was noted by Amadou Fall and Matador, who asked her to take responsibility for implementing the association's project of launching an event dedicated to women's presence in urban cultures. The project was set up in 2013. Ina helped to organize the one-day event, which took place on 8 March. On the 2014 edition, she persuaded the association to turn it into a weeklong event: Urban Women Week. 
Ina explained to the audience prior to a screening held at the end of UWW in 2014 (a presentation that was filmed and made available on YouTube) that she wanted more time for the women taking part in the festival to get to know each other to foster potential collaborations. In preparation for the 2014 event, she met with twenty-five women involved in the Senegalese hip hop scene to interview them about their involvement and the problems they faced as women in the industry. She filmed the interviews and edited them together for screening during the festival. The 2014 edition of the festival was also organized around a number of women's workshops given by the teachers from the hip hop training school. For example, a rapper offered songwriting lessons, while a dance association (which is directed by two women) ran dance lessons for girls aged twelve to sixteen. At the end of the festival, the results of the various workshops were presented at the Goethe Institute, a German cultural institute with which the association often collaborates.

It was Ina's idea to favour the more educational aspects of hip hop for women. Education for young women and men is a major part of hip hop-related activities in Senegal, as the existence of the hip hop training school and the documentation centre demonstrates. Foreign artists also provided workshops for young Senegalese during Festa $2 \mathrm{H}$. UWW therefore acted as a safe space in which women could access training in urban cultures. In 2015, leadership was the focus for the festival. In 2016, UWW promoted itself as a festival dedicated to giving visibility to women's presence and achievements in hip hop. To this end, the festival promoted the work of women though concerts, dance shows or exhibitions, workshops and lectures given by female entrepreneurs like Mariama (the creator of a dance school), Maimouna Back Again (a journalist at Vibe Radio), and Aicha Sy (blogger and cofounder of the Wakh'art Music label). The lectures created a platform for women to share their experience of the difficulties of operating in this male-dominated environment, and the ways in which they eventually became leaders within the scene.

Ina has presented the aim of the festival to the website Rapdjolof.com (Milk, 2016) as enabling women to become involved in urban cultures and to facilitate "I'expression, la visibilité et la prise de responsabilités dans l'espace public " ("selfexpression, visibility and responsibility in the public sphere"), so that they can "s'investir davantage dans le milieu hip hop en termes de visibilité, d'expression artistique, de leadership et d'entrepreneuriat " "engage more deeply in hip hop in terms of visibility, artistic expression, leadership and entrepreneurship"). This overall mission facilitates the involvement of women in hip hop through by characterising the music as an instrument of social change, promoting women's role in society as a whole.

Secondary aims of UWW are linked more directly to the promotion of women on the Senegalese rap music scene: discovering new talents, helping to obtain recognition of female artists' rights, inventorying women participating in hip hop culture, and helping to establish a network that can help artists to become more professional and to market their products. In giving female rappers a safe space in which to express themselves, the festival acknowledges the presence of women, reveals their numbers and offers them exposure. In this way, it helps to boost the visibility and legitimacy of women in hip hop. The festival is also a place where information and resources are shared. Finally, it empowers female artists by offering them access to female role models through leadership coaching, and also simply through exposure. For example, the photo shoots held during the 2016 festival gave female artists an opportunity to take away professional material with which to market themselves and at the same time a lesson in managing their image. 
Over the years, UWW has attracted support from a number of institutions. But, unlike those supporting Festa $2 \mathrm{H}$, for example, its institutional partners have until recently mostly been Senegalese or at least based in Senegal. In 2014 and 2016, the Goethe Institute was the only foreign partner and in 2015, the association partnered with another Senegalese hip hop organization.

In 2017 the festival was connected to an international agenda of promoting women in music by associating itself with Freedom Music Day, an international event organized by Danish NGO Freemuse that took place on 3 March in Switzerland, Germany, Norway, the United States, Pakistan, Morocco, Myanmar and Senegal. In Senegal, Freedom Music Day was held at the Instituto Cervantes (a Spanish cultural institute). A screening of the film Brooklyn - about a female rapper (played by Swiss rapper K-T Gorique) that had previously been screened at the 2015 Festa $2 \mathrm{H}$ - was followed by a storytelling event, with Fatim Sy, female rapper and former member of pioneering group BMG 44 and Maimouna Back Again. The organizers then extended the official international Freedom Music Day to include an additional day with a "FreeVoices show" featuring female rap acts.

In 2018, UWW took place in Dakar from 3-10 March and was part of a wider programme of events celebrating the thirtieth anniversary of hip hop in Senegal (1988-2018). The festival was supported by UNESCO following the implication of the international organization in the adoption of the Déclaration de Dakar sur l'égalité femmes/hommes dans le secteur de la musique (Dakar Declaration on Gender Equality in the Music Sector), signed in 2016 by representatives of several francophone West African countries, including the Association des Métiers de la Musique (Association for Music Professions) for Senegal. According to the Declaration, the signatories commit to working for the elaboration of propositions that sustain the achievement of equal access to music professions, the protection from violence in the workplace and the equal representation of women in musical organizations.

Debuting as the result of the individual initiative of Ina - a witness to the invisibility of women such as herself in hip hop in Senegal - UWW has increasingly connected to a national and international agenda of gender equality in the music sector. In the following section I will discuss how the organizers of UWW envision the role of the festival in terms of gender politics.

\section{The gender politics of Urban Women Week}

In the eyes of the members of the association Africulturban, as explained to me by Amadou Fall Ba regarding his other festival Festa $2 \mathrm{H}$, the role of UWW is first and foremost to act as an international platform to promote artists and talk about certain issues. What is then the role deemed to play by UWW? Is the festival just providing a temporary stage for discourses such as those advanced by the French rapper Casey quoted earlier in this article, or does it provide a platform committed to the advancement of gender issues in hip hop and in wider society?

First-and-foremost, the festival team has frequently been reluctant to link UWW to any feminist commitment. During a conference in Berlin in which Amadou Fall Ba was invited to present the different activities of Africulturban, he presented UWW as not being "about women", but about creating a space in which to show "that what men can do, women can also do". During the press conference for the 2018 Urban Women Week, Ina said that the idea of UWW was not for women "to compete" against men or to "separate men and women" but to promote representation and develop expertise among women. The message was repeated 
throughout the press conference, apparently in response to adverse criticism expected inevitably to arise from the perception of the event as being for women.

Likewise, interviews with several artists that frequently participate in UWW, as well as observations made at associated conferences, suggest that Senegalese women who testify during UWW do not conceive of their action through the feminist label. They do not think either that obstacles they face as women should be overcome by challenging gender constructions or inequalities. On the contrary, these female artists call for other women to prove themselves to be as talented as men through their own individual efforts, questioning women's own responsibilities in remaining in a marginalized status in hip hop and wider society.

On the other hand, the label "female rap" has been one of the topics frequently evoked at conferences discussing women's involvement in hip hop during UWW. The term "female rap" seems to imply that the gender of the artist influences the content or sound of the rap music produced. When I attended "Urban Women Day" in 2014, the label - although rejected by the participants as well as by some of the male members of the audience at the conference - shows how, by centring on female rappers, the identity politics of a festival promoting women in hip hop can influence such processes of labelization.

UWW, despite associating itself with international initiatives to promote gender equality in the music sector, remains firmly embedded in national meanings of what the promotion of women should involve. This local embedding is mostly signified by a break with feminist ideas they interpret as being an exclusive discourse for women, or an oppositional relationship between women and men. As a festival about women in hip hop, UWW has to face two challenges that it surpasses by not presenting itself as feminist. Indeed, by revoking the feminist label, UWW avoids being perceived as a festival that attempts to address hip hop as a patriarchal establishment. In 2018, the organizers further reduced the focus on women by programming male acts alongside female acts during the festival. Secondly, by revoking the feminist label the festival claims a level of independence from a western agenda of gender equality that could be promoted by the growing importance of foreign funders.

UWW thus adopts a narrative of neo-liberal post-feminism characterized, according to Braidotti (2005: 3), by the "replacement of feminism by the less confrontational policy of gender mainstreaming". However, this gender mainstreaming, while being embedded in global processes is also, in the case of UWW, a response to globalization and neo-colonial agendas. Indeed, feminism is here also discussed in relation to issues of democracy and Western agendas. Can Western states impose on Africa a definition of democracy? Can they impose their views on acceptable gender relations? Questioning a Western conceptualisation of feminism is for the members of the association a way to distance themselves from Western gender politics that, according to the organizers of the festival, do not take into account the religious and social contexts of the countries in which the West seeks to impose specific agendas.

The increasingly embedded nature of UWW in Senegal and in the Senegalese hip hop scene therefore supports the aims of the festival and increases the visibility of women in the scene, while restraining this space to a form that continues to be acceptable to men in the scene. Rather than deconstructing gender differences, UWW asks female artists to prove their value in a man's world and aims to provide women with a platform and tools. The festival's capacity to challenge more broadly the patriarchal structure of hip hop is therefore limited. The festival places less emphasis on the specific discrimination faced by women than on their perceived limitations within the scene, and which are in turn viewed as central to issues of 
gender inequality in Senegalese hip hop. For example, their perceived lack of leadership skills (in which they need to be trained) is thought to prevent them from assuming a greater role. In this way, the festival reproduces gender stereotypes. This reproduction of gender stereotypes becomes increasingly evident when the importance of UWW within the agenda of the association and women's representation in other events are considered. Indeed, while the association claims not to discriminate between men and women, its organizers have long failed to take account of the male hegemony that prevails in the association's other events.

In 2015, women were invited to an "urban women day" at Festa $2 \mathrm{H}$, but I noticed that no women were invited on the other days of the festival. When I raised this issue with the festival organizer, Amadou Fall Ba, he told me that:

It's a pity but that's how it is. There just aren't any women who count in hip hop (...) Apart from the one who played in Flow Up [the association's annual rap competition, in which just one girl took part that year], the rest don't really do rap. We can't promote that, you see. These girls aren't up to it. That's how it is, unfortunately. (Interview, 2015, translation from original quote in french)

The association had invited several women to appear at UWW earlier the same year, including Toussa, Déesse Major and OMG, but they were not invited to appear at Festa $2 \mathrm{H}$. The invitations to UWW implied that the association recognized the existence of female rappers deemed good enough to play at a festival dedicated to women but did not consider them good enough to be invited to an international, male-dominated festival like Festa $2 \mathrm{H}$. The association has however recently announced the programme of 2018's edition of Festa $2 \mathrm{H}$, happening from June 21 to June 24, in which appear two female groups than the association has supported. Time will tell if UWW will have a deeper influence on the association as a whole as well as on Senegalese hip hop scene. In the meantime, women who participate in UWW have access to a temporary safe space, a space in which they can talk about issues, learn, support and gain support from other women in the scene.

\section{Conclusion}

In this article, I considered the issue of the promotion of women in the music industry from the point of view of the strategies of the organizers of a hip hop festival in Senegal: Urban Women Week. I anchored my understanding of the creation of such festival in the religious and traditional references that have been mobilized in Senegalese nation-building process during the first decades of independence and are still mobilized today to affirm a Senegalese national identity that in turn relates to specific gender norms. In this context, as it is true elsewhere, I argue that rap is a place where such gender norms are both re-enacted and challenged. I then explored the festival as emerging out of a primarily male organisation that aims to promote urban cultures in Senegal. In an attempt to highlight the issues faced by women in the Senegalese hip hop scene, an opportunity was provided for its sole female member, Ina. This approach is mirrored in UWW's tokenistic engagement with a national and international agenda of gender equality in the music sector. Finally, by exploring how the association positioned the festival in regard to a feminist agenda, I discussed the negotiations the organizers had to make between local and global meanings of gender politics and the limits that it posed to their concrete result on the advancement of women in Senegalese hip hop scene. 
A Western onlooker may wonder, like American blogger Katie Kelly who attended UWW in 2017, "is this the best way to empower Senegalese women?" (Kelly 2017: web source). From the point of view of the organizers of the festival, the promotion of women on the hip hop scene is a cause they have chosen to address because the matter is deemed to be of importance, and because there was the opportunity to address it. Urban Women Week is also Ina's particular project, which she has decided is worth pursuing, demonstrating the potential influence of individual women within the scene.

As such, without being feminist in the Eurocentric sense of the term, and despite being associated with global initiatives like Freemuse and UNESCO, UWW participates in the promotion of women in music festivals by articulating a gender agenda that is compatible both with hip hop culture as appropriated in Senegal and with the local religious context, yet prevents any radical subversion of Senegalese patriarchal hip hop establishment and a questioning of wider gender norms within Senegal.

\section{Endnotes}

1 All statements quoted in this article are either statements made in public or statements made during recorded interviews for which the participants declined their right to anonymity. No pseudonyms have been used.

\section{References}

\section{Bibliography}

Aitchison, C. and Pritchard, A. 2007. Festivals and Events: Culture and ldentity in Leisure,Sport and Tourism. Eastbourne: Leisure Studies Association.

Askew K. 2002. Performing the Nation: Swahili Music and Cultural Politics in Tanzania. Chicago: University of Chicago Press.

Atelier sous-régional sur l'égalité femmes/hommes dans le secteur de la musique. 2016. Déclaration de Dakar sur l'égalité femmes/hommes dans le secteur de la musique. Dakar, 11-13 January 2016.

Aterianus-Owanga, A. 2013. Un rap "incliné sur la force": La fabrique de la masculinité sur la scène rap librevilloise. Cahiers d'Etudes africaines 1(209-

210): 143-172. http://www.cairn.info/revue-cahiers-d-etudes-africaines-2013-1page-143.htm Accessed: 17 April 2016.

Bennett, A. and Peterson Richard A. 2004. Music Scenes: Local, Translocal and Virtual. Nashville: Vanderbilt University Press.

Biaya, T. K. 2001. Les plaisirs de la ville : Masculinité, sexualité et féminité a Dakar (1997-2000). African Studies Review 44 (2): 71-85.

Black Milk. 2016. Urban Women Week 4ème Édition: Du 29 Février au 08 Mars 2016. Rap Djolof / \#1 Hip Hop Senegal. http://rapdjolof.com/webzine/news/item/3258-urban-women-week-4emeedition-du-29-fevrier-au-08-mars-2016 Accessed: 3 March 2016.

Braidotti R. 2005. A Critical Cartography of Feminist Post-postmodernism. Australian Feminist Studies 20 (47): 169-180.

Buscatto M. 2008. Attempting, Returning, Staying: Three Challenges of Female Jazz Instrumentalists. Travail, genre et sociétés 19 (1): 87-108. 
Cheney, C. 2005. Brothers Gonna Work It Out: Sexual Politics in the Golden Age of Rap Nationalism. New York: NYU Press.

DeBano W. S. 2005. Enveloping music in gender, nation, and Islam: Women's music festivals in post-revolutionary Iran. Iranian Studies 38 (3): 441-462.

De Genova, N. 1995. Gangster rap and nihilism in Black America: some questions of life and Death. Social Text, 43: 89-132.

Dial, F. B. 2008. Mariage et divorce a Dakar. Itinéraires féminins. Paris: KarthalaCREPOS.

Diouf, M. 2002. Les cultures urbaines entre traditions et mondialisation. In M-C. Diop Ed. Le Sénégal contemporain. Paris : Karthala, 261-288.

Eder D., Staggenborg S. and Sudderth L. 1995. The National Women's Music Festival: Collective Identity and Diversity in a Lesbian-Feminist Community. Journal of Contemporary Ethnography 23 (4): 485-515.

Gamson J. 1996. The organizational shaping of collective identity: The case of lesbian and gay film festivals in New York. Sociological Forum 11(2): 231-261.

Getz, D. 2010. The Nature and Scope of Festival Studies. International Journal of Event Management Research 5 (1): 1-47.

Gifford, P. 2016. Religion and politics in contemporary Senegal. African Affairs 115 (461): 688-709. http://dx.doi.org/10.1093/afraf/adw047

Higgins, L. L. 2008. Reconstructing Gender, personal narrative, and Performance at the Michigan womyn's music festival. University of Missouri-Columbia: Thesis for the status of Doctor of Philosophy.

hooks, B. 1992. Black Looks: Race and Representation. Boston: South End Press.

Jeffries, M. P. 2012. Hip hop Feminism and Failure. Palimpsest: A Journal on Women, Gender and the Black International 1 (2): 277-284. https://muse.jhu.edu/article/500179 Accessed: 3 January 2018.

Kelly, K.T. 2017. "What happened at Urban Women Week?", Conversing 'bout climate justice. Blog of Katie Kelly.

https://ds.Iclark.edu/ktkelly/2017/10/02/what-happened-at-urban-women-week/ Accessed: 11 November 2017.

Locoh T. et Puech I. 2008. Fatou Sow. Les défis d'une féministe en Afrique. Travail, genre et sociétés 20 (2): 5-22.

Maule, R. 2014. Women's festival 2.0 between Grassroots Globalization and neoliberal Feminism: the Birds Eye View festival. Communicazioni sociali, 3: 368-374.

Mine, D. 2016. Exclusif : La chanteuse Déesse Major placée en garde a vue. Seneweb.com. http://www.seneweb.com/news/People/exclusif-la-chanteusedeesse-major-place n 185317.html Accessed: 20 June 2016

Mitchum B. and Garcia-Olano D. 2017. Are Music Festival Lineups Getting Worse? Pitchfork. https://pitchfork.com/features/festival-report/10059-aremusic-festival-lineups-getting-worse/ Accessed: 17 April 2018.

Mondain, N. et al. 2012. Les effets de l'émigration masculine sur les femmes et leur autonomie : entre maintien et transformation des rapports sociaux de sexe traditionnels au Sénégal. Autrepart 61: 81-97.

http://www.cairn.info/resume.php?ID ARTICLE=AUTR 0610081 Accessed: 26 April 2016.

Munck-Lindblom, M. 2014. The Leading Graffiti Artist of Senegal is a Woman. Rapolitics. http://www.rapolitics.org/the-leading-graffiti-artist-of-senegal-is-awoman/ Accessed: 27 Dec 2014. 
Niang, A. 2013. Le Mouvement Hip Hop au Sénégal : des marges a une légitimité sociale montante. In M-C. Diop Ed. Le Sénégal sous Abdoulaye Wade. Paris: Karthala Editions: 569-590.

Neff, A. C. 2015. Roots, Routes and Rhizomes: Sounding Women's Hip Hop on the Margins of Dakar, Senegal. Journal of Popular Music Studies 27 (4): 448477. http://dx.doi.org/10.1111/jpms.12157

Ntarangwi, M. 2009. East African Hip Hop: Youth Culture and Globalization. Champaign: University of Illinois Press.

Pough, G. D. 2007. What It Do, Shorty?: Women, Hip-Hop, and a Feminist Agenda. Black Women, Gender + Families 1(2): 78-99. http://www.jstor.org/stable/10.5406/blacwomegendfami.1.2.0078 Accessed Online 3 January 2018.

Salzbrunn M. 2012. Le religieux et le politique en Afrique musulmane francophone. Une pratique souple de la lancité en Côte d'Ivoire et au Sénégal. In J. Ehrenfreund and P. Gisel Eds. Religieux, société civile, politique. Enjeux et débats historiques et contemporains. Lausanne: Antipodes: 135-160.

Sow, F. 2003. Fundamentalisms, globalisation and women's human rights in Senegal. Gender and Development 11(1): 69-76.

Triaud, J.-L. 1995. Senegal. Encyclopedia of Islam. Leiden: Brill.

Vignikin, K. 2007. Famille et relations intergénérationnelles. Réflexions sur les évolutions en cours en Afrique. In P. Antoine Ed. Les Relations intergénérationnelles en Afrique. Approche plurielle. Paris: Les collections du Ceped: 19-30.

White, M. 2011. From Jim Crow to Jay- $Z$ : Race, Rap, and the Performance of Masculinity. Champaign: University of Illinois Press.

\section{Discography}

Elzo Jamdong. 2016. "Yow Lë", Freengdom, Oven Entertainment, 27 May 2016, Senegal.

\section{Interviews}

Amadou Fall Ba. 2015. Interviewed by the author, Dakar, 13 June.

Casey et al. 2015. Conference "Les femmes engagées dans le Hip Hop". Urban Women Day. Dakar, 12 June.

Deése Major. 2015. Interviewed by the author, Dakar, 26 January.

Amadou Fall Ba et al. 2017. Conference "From Zero to Hero". Hollyhood: Hip Hop and Social Justice. Berlin, 12 March.

Urban Women Week. 2014. Film Screening and Presentation of the Results of the workshops. Goethe institute, Dakar, 7 March.

Urban Women Week. 2018. Press conference. Goethe Institute, Dakar, 6 March. 